\title{
Angiotensin II promotes melanogenesis via angiotensin II type 1 receptors in human melanocytes
}

\author{
LI-HONG LIU ${ }^{1,2}$, XIN FAN $^{2}$, HAI-TAO LI ${ }^{2}$, XU-XI AN ${ }^{2}$ and RONG-YA YANG ${ }^{2}$ \\ ${ }^{1}$ Graduate School, The Third Military Medical University, Chongqing 400038; ${ }^{2}$ Department of Dermatology, \\ General Hospital of Beijing Military Region of PLA, Beijing 100700, P.R. China
}

Received May 22, 2014; Accepted February 13, 2015

DOI: $10.3892 / \mathrm{mmr} .2015 .3438$

\begin{abstract}
Angiotensin II (AngII) is a hormone with long-established cardiovascular actions. Previous studies have revealed an additional role for AngII in the regulation of cutaneous wound healing. To evaluate the association between AngII and abnormal pigmentation of cutaneous wound healing, the present study used human melanocytes to investigate the effects of AngII on melanogenesis, and to elucidate the possible underlying mechanisms. Primary culture melanocytes were treated with AngII either alone or in combination with an AngII type 1 (AT1) receptor antagonist, losartan (LOS). The melanin content and tyrosinase activity were measured and reverse transcription-quantitative polymerase chain reaction (RT-qPCR) and western blotting were performed to assess the proteins involved in melanogenesis and the AT1 receptor. AngII regulated the mRNA expression of ATI in the melanocytes. The melanin content and tyrosinase activity increased in response to treatment with AngII in a concentration-dependent manner. RT-qPCR and western blotting revealed that the AT1 receptor antagonist, LOS, eliminated this effect. These results provide a novel insight into the role of AngII and its associated signaling in melanogenesis.
\end{abstract}

\section{Introduction}

Abnormally pigmented scars are an undesirable consequence of cutaneous wound healing and are a complication for which every individual worldwide is at risk. Abnormal pigmentation renders scars more noticeable, which can have serious and profound psychological implications $(1,2)$.

The production of pigment is complex and controlled by several extrinsic and intrinsic factors, and scar repigmentation patterns cannot be predicted. As there are currently no

Correspondence to: Dr Rong-Ya Yang, Department of Dermatology, General Hospital of Beijing Military Region of PLA, 5 Nanmencang Street, Beijing 100700, P.R. China

E-mail: liulihongzjk@sina.com

Key words: melanogenesis, angiotensin II, wound healing, tyrosinase regulation, angiotensin II type 1 receptor definitive treatment options available, this presents a challenge to physicians. Therefore, the identification of key molecules, which modulate the mechanism of abnormal pigmentation is of significant interest.

Previous studies have demonstrated that angiotensin II (AngII) may be involved in all stages of wound healing (3), including inflammatory cell invasion, cell proliferation, cell migration, neovascularization and fibrosis (4). AngII has been observed to increase vascular permeability, recruit inflammatory cells $(5,6)$, and promote keratinocyte proliferation $(4,7,8)$ and dermal wound closure (9).

Steckelings et al first described the expression and putative role of AngII in human skin (10), and the regulation of keratinocyte, dermal myofibroblast, and endothelial cell proliferation have also been reported $(9,11)$. Steckelings et al (10) reported that human skin expresses AngII type 1 (AT1) receptors and type 2 (AT2) receptors, which were suggested to be involved in skin wound healing (3). Steckelings et al (12) later demonstrated that the expression levels of the AT1 and AT2 receptors was markedly increased within the epidermal and dermal areas of scars. In addition, Otake et al reported that inhibition of the AT1 receptor limited murine melanoma growth by reducing tumor volume and microvessel density, demonstrating the importance of AT1 receptors in melanoma growth (13). A previous study also investigated the mRNA expression of $A T 1$, but not $A T 2$, in cultured primary melanocytes (10).

Although several functional roles of AngII have been suggested, whether AngII induces abnormal pigmentation by regulating the melanocyte system during wound healing remains to be elucidated. In the present study, the functional role of AngII in human melanocytes was investigated, and alterations in human melanocytes were characterized.

\section{Materials and methods}

Compounds and drugs. Rabbit polyclonal anti-AT1 antibodies (sc-1173), mouse polyclonal anti-tyrosinase antibodies (sc-20035) and horseradish peroxidase-linked goat anti-rabbit (sc-2004) or goat anti-mouse (sc-2005) antibodies were purchased from Santa Cruz Biotechnology, Inc. (Santa Cruz, CA, USA). A protein quantification kit and agarose were purchased from Bio-Rad Laboratories, Inc. (Hercules, CA, USA). Polymerase chain reaction (PCR) Master Mix was purchased from Promega (Madison, WI, USA). The 
commercial sources of other products were as follows: Gentamicin, phosphate-buffered saline (PBS), M254 medium and human melanocyte growth supplements were from Cascade Biologics (Mansfield, UK); fetal bovine serum (FBS) and RNeasy mini kit were from Qiagen (Valencia, CA, USA); AngII, the AT1 receptor antagonist, losartan (LOS), ethidium bromide, $\mathrm{NaCl}, \mathrm{KH}_{2} \mathrm{PO}_{4}, \mathrm{CaCl}_{2}, \mathrm{MgSO}_{4}$, L-3,4-dihydroxyphenylalanine (L-DOPA), glucose, bovine serum albumin, EDTA, glycine, sodium dodecyl sulfate (SDS) and Tris were from Sigma-Aldrich (St. Louis, MO, USA).

Melanocyte culture. Normal melanocytes were isolated from the epidermis of human foreskins obtained from the Department of Urology (General Hospital of Beijing Military of PLA, Beijing, China). The present study was approved by the ethics committee of the General Hospital of Beijing Military of PLA. Written informed consent was obtained from the patients. The skin grafts were cut into small sections (5x5 mm) and incubated with trypsin-EDTA (2.5 g/l trypsin, $0.2 \mathrm{~g} / \mathrm{l}$ EDTA) at $4^{\circ} \mathrm{C}$ overnight. Trypsin activity was required to separate the epidermis from the dermis. The following day, trypsin activity was neutralized by adding FBS at a 1:1 ratio, and replacing it with PBS solution. The epidermis was separated from the dermis using sterile forceps. Thorough pipetting was performed to separate the cells, resulting in the formation of and cell-rich suspensions. The solid tissue waste was removed and the suspension was centrifuged at $1,000 \mathrm{x} g$ for $5 \mathrm{~min}$. The melanocytes were selectively grown in defined M254 medium supplemented with human melanocyte growth supplements. The number of cells was adjusted to $2.5 \times 10^{4}$ cells $/ \mathrm{cm}^{2}$ and the cultures were maintained at $37^{\circ} \mathrm{C}$ in a humidified $95 \%$ air and $5 \% \mathrm{CO}_{2}$ atmosphere. The medium was replaced at 2-3-day intervals. The cultures were routinely examined for contamination and cell outgrowth. The cells were then split, at confluence, by $5 \mathrm{~min}$ trypsin $(2.5 \mathrm{~g} / \mathrm{l})$ treatment at room temperature. The cells were subcultured once per week and experiments were performed using cells between passages two and four.

Treatment with AngII alone or in combination with AT1 receptor antagonists. The confluent cells were seeded at sub-confluent densities $\left(2 \times 10^{5}\right.$ cells $)$ in 6 -well plates and were grown for 4 days, until confluent. The cells were subsequently treated with different concentrations of AngII $(0.01,0.1,1,10$ and $100 \mathrm{nM})$ for $24 \mathrm{~h}$ at $37^{\circ} \mathrm{C}$. In certain experiments, the cells were exposed to $1,000 \mathrm{nM}$ LOS, an AT1 receptor antagonist, in addition to the AngII, and/or were exposed to LOS for $30 \mathrm{~min}$ prior to AngII stimulation. The culture medium was removed and the cells were washed twice with PBS prior to adding fresh assay medium supplemented with $0.1 \%$ FBS for $24 \mathrm{~h}$. Following culture, a melanin content assay was performed, and tyrosinase activity and cell proliferation were measured. The cell homogenates and supernatants were collected for RNA extraction using an RNeasy mini kit (Bio-Rad Technologies, Inc.) for protein quantification, based on the Bradford method (14).

Tyrosinase activity assay. The melanocytes were treated with AngII and/or LOS for $24 \mathrm{~h}$ and were subsequently washed with ice-cold 1X PBS. Lysis buffer, containing
$150 \mu 11 \%$ Triton X-100 in $0.1 \mathrm{M}$ phosphate buffer, was added to each 6-well plate. The cells were scraped and transferred to a $1.5 \mathrm{ml}$ tube, lysed using between three and five freeze-thaw cycles in liquid nitrogen, and centrifuged at 5,000 x $\mathrm{g}$ for $5-10 \mathrm{~min}$ at $4^{\circ} \mathrm{C}$. The samples $(300-500 \mu \mathrm{g} / 80 \mu \mathrm{l})$ were transferred into a new 96-well plate on ice. L-DOPA $(20 \mu \mathrm{l} ; 5 \mathrm{mM})$ was added to each well, the plate was incubated at $37^{\circ} \mathrm{C}$ for $1 \mathrm{~h}$ and the absorbance was measured at $475 \mathrm{~nm}$ using a spectrophotometer (DU-70; Beckman Coulter, Brea, CA, USA).

Melanin content assay. The melanin content was determined, as described previously (15). Briefly, the cells were lysed with $200 \mu \mathrm{l} 1 \mathrm{M} \mathrm{NaOH}$ and pipetted repeatedly to homogenize the samples. The cell extract was subsequently transferred into 96-well plates, and the relative melanin content was determined by measuring the absorbance at $405 \mathrm{~nm}$ using an enzyme-linked immunosorbent assay (ELISA) plate reader (Synergy H1MF; BioTek, Winooski, VT, USA).

Tetrazolium assay. A 3-(4,5-dimethylthiazol-2-yl)-2,5-diphenyltetrazolium bromide (MTT) yellow tetrazole assay was performed to investigate cell proliferation (14). Following the treatment with Ang II and/or LOS, $100 \mu$ l aliquots of the cells were harvested, as detailed above, and plated in flat-bottomed 96-well plates $\left(2.5 \times 10^{4}\right.$ cells $\left./ \mathrm{cm}^{2}\right)$. The cells were allowed to attach and grow overnight at $37^{\circ} \mathrm{C}$. The MTT assay was performed, according to the manufacturer's instructions. The formazan precipitates were quantified by measuring the absorbance at $562 \mathrm{~nm}$ using an ELISA plate reader.

$R T-q P C R$. The total RNA extraction and RT reaction were performed, as described previously (16), and the mRNA expression levels of ATl and tyrosinase were evaluated using qPCR. The total RNA was extracted $24 \mathrm{~h}$ after drug treatment using a TRIzol kit (Invitrogen Life Technologies, Carlsbad, CA, USA) and reverse-transcribed using an RT kit (ReverTra Ace ${ }^{\circledR}$ qPCR RT kit; Toyobo, Osaka, Japan). Semi-qPCR was performed using primers (Table I) for the AT1 receptor and tyrosinase (Beijing Dingguo Biological Technology Co., Ltd., Beijing, China). The qPCR was performed using a C100 Thermal Cycler (Bio-Rad Laboratories, Inc.) and a touchdown protocol, as described previously (17), using the following program: 1 cycle at $94^{\circ} \mathrm{C}$ for $2 \mathrm{~min}, 12$ cycles at $92^{\circ} \mathrm{C}$ for $20 \mathrm{sec}, 68^{\circ} \mathrm{C}$ for $30 \mathrm{sec}$ and $70^{\circ} \mathrm{C}$ for $45 \mathrm{sec}$ (with a decrease of $1^{\circ} \mathrm{C}$ per cycle) and 22 cycles at $92^{\circ} \mathrm{C}$ for $20 \mathrm{sec}, 55^{\circ} \mathrm{C}$ for $30 \mathrm{sec}$ and $70^{\circ} \mathrm{C}$ for $45 \mathrm{sec}$. The PCR products were separated by electrophoresis using $2 \%$ agarose gels and visualized by ethidium bromide $(0.5 \mu \mathrm{g} / \mathrm{ml})$ staining for $5 \mathrm{~min}$ at room temperature. The PCR band intensity was determined using Quantity One software (v4.62; Bio-Rad Laboratories, Inc.), and was expressed as the relative intensity against that of $\beta$-actin.

Western blotting. The protein expression levels of AT1 and tyrosinase were assessed by western blotting. The human foreskin were cut into small sections and incubated with trypsin-EDTA (2.5 g/l trypsin, $0.2 \mathrm{~g} / 1$ EDTA) at $4^{\circ} \mathrm{C}$ overnight. Trypsin activity was required to separate the epidermis from the dermis. Subsequently, the menlanocytes were isolated and cultured, and treated with AngII alone or in combination with AT1 receptor antagonists. The menlanocytes were 
Table I. Primers used in the reverse transcription-quantitative polymerase chain reaction.

\begin{tabular}{ll}
\hline Primer & \multicolumn{1}{c}{ Sequence $\left(5^{\prime}-3^{\prime}\right)$} \\
\hline $\begin{array}{l}\text { Angiotensin II type } 1 \\
\text { Forward }\end{array}$ & \\
Reverse & ATTGCCAACAGCCTATCT \\
Tyrosinase & CCATCCTCCTGGTCCTTA \\
Forward & \\
Reverse & ACGATGTGGACGAGTGT \\
$\beta$-actin & CAGAGGCAGGTGAAGGT \\
Forward & \\
Reverse & ATCATGTTTGAGACCTTCAACA \\
\hline
\end{tabular}

then collected in lysis buffer and centrifuged for $30 \mathrm{~min}$ at $15,000 \mathrm{x} \mathrm{g}$ at $4^{\circ} \mathrm{C}$. The supernatant was collected and the protein concentration was determined using the bicinchoninic acid method (Bio-Rad Laboratories, Inc.). The proteins $(20 \mu \mathrm{g})$ were denatured with SDS sample buffer, boiled for $5 \mathrm{~min}$ and separated onto 10-12\% polyacrylamide gels (Novex, San Diego, CA, USA). Following electrophoresis, the proteins were transferred into $1 \mathrm{X}$ transfer buffer, containing $25 \mathrm{mM}$ Tris, $192 \mathrm{mM}$ glycine and $0.1 \% \mathrm{SDS}$ and $20 \%$ methanol (pH 8.4), onto a $0.45 \mu \mathrm{m}$ Immobilon-P polyvinyl difluoride membrane (Millipore, Temecula, CA, USA) in a Mini Protean II transfer cell (Bio-Rad Laboratories, Inc.) set at a constant voltage of $120 \mathrm{mV}$ for $2 \mathrm{~h}$. The membranes were blocked in 5\% non-fat dry milk in Tris-buffered saline (TBS) for at least $1 \mathrm{~h}$ at room temperature. The blots were subsequently incubated overnight at $4^{\circ} \mathrm{C}$ with either rabbit anti-AT1 or mouse anti-tyrosinase (1:1,000 dilution). The membranes were washed three times with TBS containing 1\% Triton X-100 (TBS-T), incubated with horseradish peroxidase-linked goat anti-rabbit or goat anti-mouse antibodies (1:2,000 dilution) for $2 \mathrm{~h}$ at room temperature and were ten washed four times with TBS-T. The immunoreactive bands were visualized by exposing the membrane blots to an enhanced chemiluminescence substrate (Thermo Fisher Scientific, Waltham, MA, USA), and the proteins of interest were visualized on X-ray film (BT Film; Carestream Health, Xiamen, China). Three independent experiments were performed in triplicate.

Statistical analysis. Statistical analyses were performed using SPSS 14.0 (SPSS, Inc., Chicago, IL, USA). The data are expressed as the mean \pm standard error of the mean. Statistical analysis between groups was performed using analysis of variance. $\mathrm{P}<0.05$ was considered to indicate a statistically significant difference.

\section{Results}

AngII regulation of tyrosinase activity, melanin content and cell proliferation via the AT1 receptor. Tyrosinase activity and melanin content increased significantly in a dose-dependent manner following treatment with AngII (Fig. 1A and C). There were significant increases in the activity of tyrosinase and melanin content following incubation of the cells with increasing concentrations of AngII (0.1-100 nM) and AngII (10-100 $\mathrm{nM}$ ) for $24 \mathrm{~h}$, respectively. The maximal increase was observed with $100 \mathrm{nM}$ AngII $(\mathrm{P}<0.01)$. An increase of $\sim 17 \%(114 \pm 16.89 ; \mathrm{P}<0.05)$ in tyrosinase activity was observed following treatment with $100 \mathrm{nM}$ AngII (Fig. 1A). Treatment with $<0.01 \mathrm{nM}$ AngII had no effect on tyrosinase activity compared with the control (Fig. 1A). At 0.01-1 nM AngII, no difference in melanin content was observed compared with the control (Fig. 1C). The tyrosinase activity and melanin content were inhibited following incubation with $100 \mathrm{nM}$ AngII alone for $24 \mathrm{~h}$ or following exposure to $1 \mu \mathrm{M}$ LOS, a selective AT1 receptor antagonist, for $30 \mathrm{~min}$ prior to AngII treatment (Fig. 1B and D). There was a marginal, but non-significant increase in cell proliferation ( $\mathrm{P}>0.05$; Fig. 1E).

AngII regulation of the $m R N A$ expression of AT1. Previous studies have reported that AngII regulates the expression levels of the AngII receptor subtypes in non-ocular tissues and in human retinal pigment epithelium tissues $(18,19)$. Steckelings et al examined cultured primary melanocytes and examined the mRNA expression of AT1, but not AT2 (10). The present study investigated whether AngII modulates the expression of the AT1 receptor in cultured human melanocytes. To determine the effective range of AngII, the cells were treated with 0.01-100 nM AngII for $24 \mathrm{~h}$, and the AngII modulation of the expression of $A T 1$ was assessed. At 0.1-100 nM, AngII increased the mRNA expression of ATl. The maximal increase was observed at $100 \mathrm{nM}$ AngII, increasing the mRNA expression of AT1 2.7-fold $(63.21 \pm 10.59 \%$; $\mathrm{P}<0.01)$. Treatment with $10 \mathrm{nM}$ AngII increased the mRNA expression of AT1 1.67-fold (38.94 $\pm 6.54 \%$; $\mathrm{P}<0.01)$, whereas 0.1 and $1 \mathrm{nM}$ AngII increased the mRNA expression levels of AT1 1.44- and 1.53-fold (33.47 \pm 3.91 and 35.54 $\pm 6.821 \%)$ respectively $(\mathrm{P}<0.05)$. However, treatment with $0.01 \mathrm{nM}$ AngII had no effect on the mRNA expression of AT1 compared with the control (Fig. 2). Pretreatment with LOS prevented the maximal upregulation of the mRNA expression of ATl by $100 \mathrm{nM}$ AngII (Fig. 2). Therefore, AngII regulated the mRNA expression of ATl in human melanocytes and LOS inhibited these effects.

Regulation of the $m R N A$ and protein expression levels of tyrosinase by Ang II via the AT1 receptor. Tyrosinase is the key regulatory enzyme in melanin biosynthesis (20). The 
A

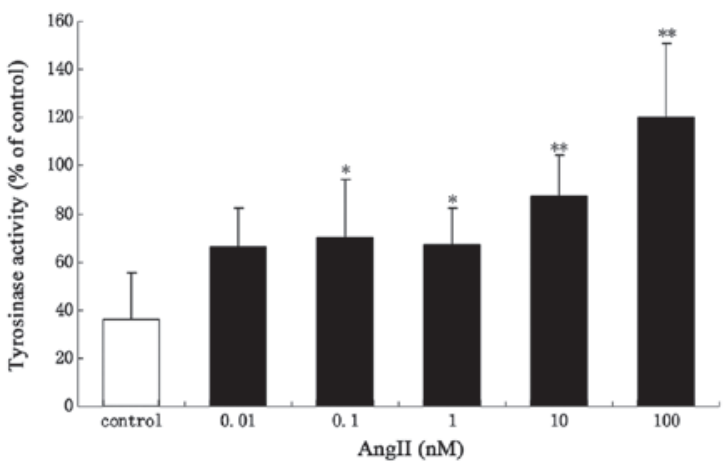

B

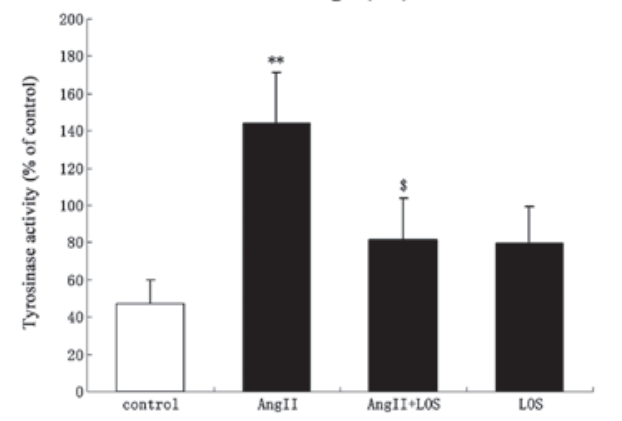

C

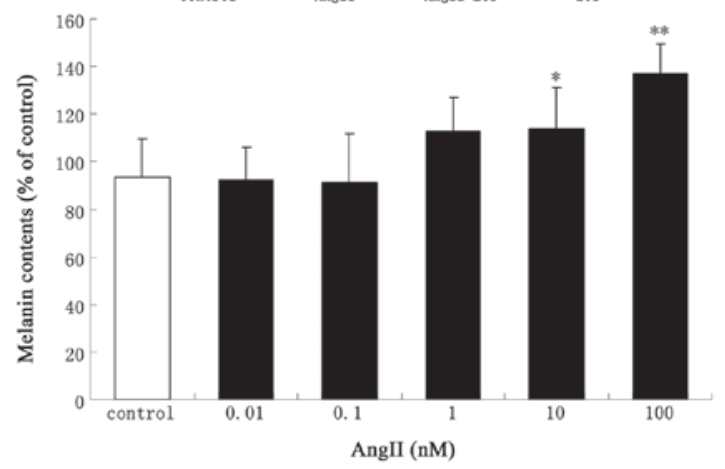

D

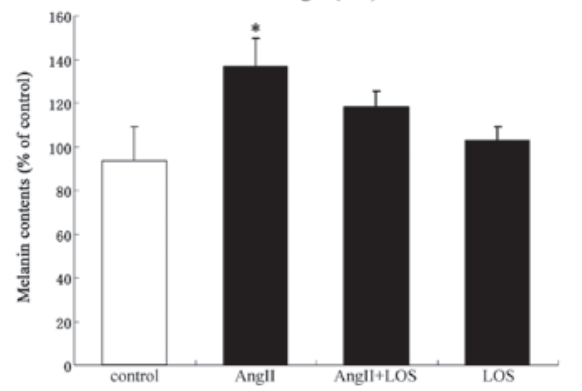

E

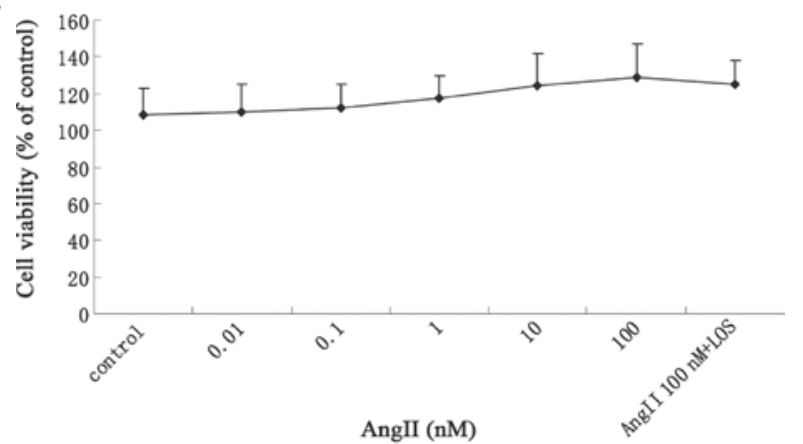

Figure 1. (A) Tyrosinase activity following treatment with different concentrations of Ang II and (B) following treatment with Ang II and LOS, either alone or in combination. (C) melanin content following treatment with different concentrations of Ang II and (D) following treatment with Ang II and LOS, either alone or in combination. (E) MTT assay of melanocyte cell viability following treatment with different concentrations of AngII. Data are expressed as the mean \pm standard error of the mean. ${ }^{*} \mathrm{P}<0.05$ and ${ }^{* *} \mathrm{P}<0.01$, vs. control; ${ }^{\$} \mathrm{P}<0.05$, vs. $100 \mathrm{nM}$ AngII. Ang, angiotensin; LOS, losartan.
A

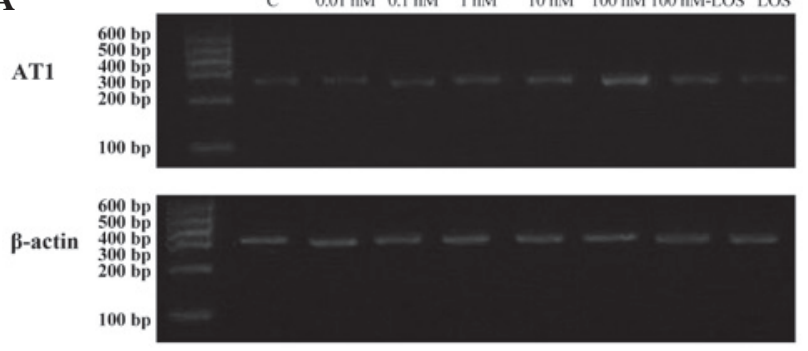

B

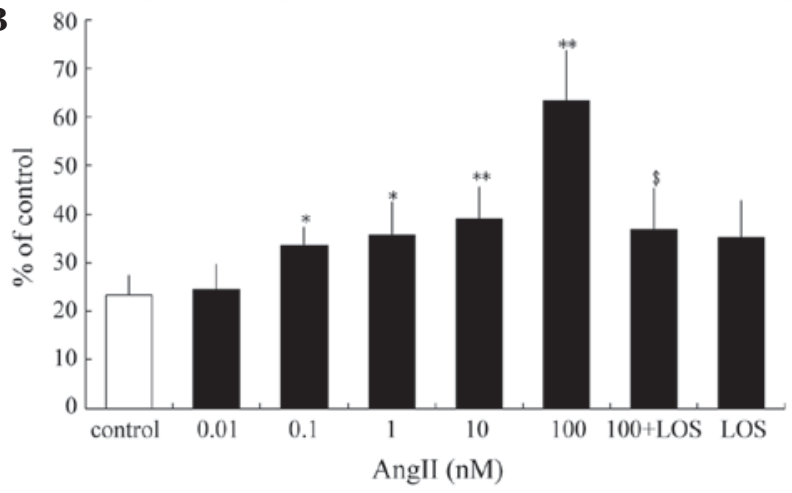

Figure 2. AngII upregulates the mRNA expression of AT1 cultured human melanocytes, and selective AT1 antagonists inhibit the effect. (A) Reverse transcription-quantitative polymerase chain reaction analysis of ATl in the presence of different concentrations of AngII alone for $24 \mathrm{~h}$ or exposed to LOS $(1 \mu \mathrm{M})$ for 30 min prior to AngII stimulation. (B) The mRNA expression of AT1 was normalized against $\beta$-actin. Data are expressed as the mean \pm standard error of the mean and were confirmed by three independent experiments. ${ }^{*} \mathrm{P}<0.05$ and ${ }^{* *} \mathrm{P}<0.01$, vs. control; ${ }^{\$} \mathrm{P}<0.05$, vs. $100 \mathrm{nM}$ AngII. C, control; Ang, angiotensin; LOS, losartan; AT1, Ang type 1.

present study examined whether AngII alters the mRNA and protein expression levels of tyrosinase in human melanocytes. RT-qPCR analysis of tyrosinase revealed no changes in transcription following $24 \mathrm{~h}$ incubation with $0.01 \mathrm{nM}$ AngII (Fig. 3). However, significant increases in transcription were observed following $24 \mathrm{~h}$ incubation with higher concentrations of AngII (0.1-100 nM; Fig. 3).

Following incubation with 0.1 and $1 \mathrm{nM}$ AngII, there was an increase of 38.562 and $46.259 \%(\mathrm{P}<0.05)$, respectively) and a 57\% increase $(\mathrm{P}<0.01)$ following treatment with $10 \mathrm{nM}$ AngII (Fig. 3). A maximal increase of 59.5\% (P<0.01) was observed following treatment with $100 \mathrm{nM}$ AngII (Fig. 3). However, pretreatment with LOS eradicated this effect (Fig. 3B). Western blotting was performed to compare the effect of AngII on the ratio of secreted tyrosinase protein. Following $24 \mathrm{~h}$ incubation with $100 \mathrm{nM}$ AngII, there was a significant increase in tyrosinase in the melanocytes (Fig. 4). Pretreatment with LOS prevented the AngII-induced increase in protein expression levels of tyrosinase and ATl (Fig. 4), suggesting that the ATI receptor mediates the AngII-induced increase of tyrosinase in human melanocytes and that it is coupled to tyrosinase signaling.

\section{Discussion}

Despite extensive investigations on pigment cells and wound healing, current understanding of scar repigmentation following cutaneous injury remains limited, and the mechanisms associating AngII with abnormal pigmentation 
A
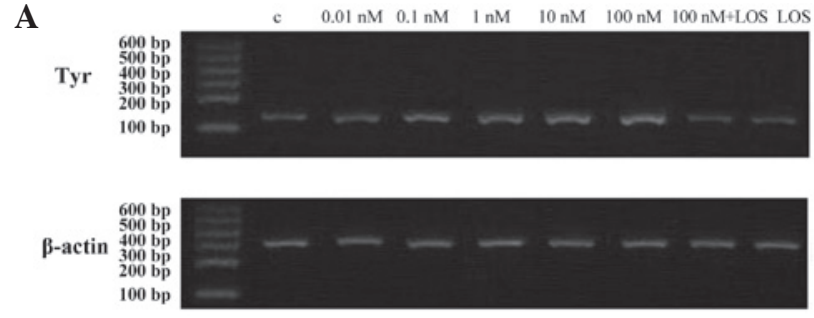

B

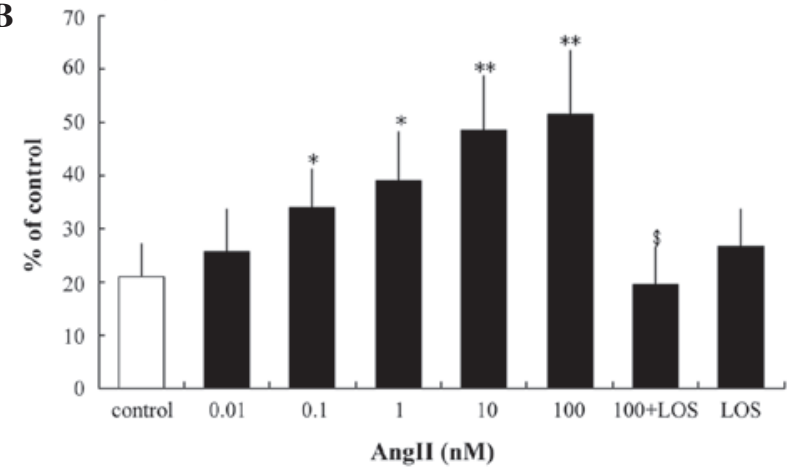

Figure 3. AngII upregulates the mRNA expression of tyrosinase in cultured human melanocytes, and selective AT1 antagonists inhibit the effect. (A) Reverse transcription-quantitative polymerase chain reaction analysis of levels of tyrosinase in the presence of different concentrations of AngII alone for $24 \mathrm{~h}$ or exposed to LOS $(1 \mu \mathrm{M})$ for $30 \mathrm{~min}$ prior to AngII stimulation. (B) mRNA expression of tyrosinase was normalized against $\beta$-actin The data are expressed as the mean \pm standard error of the mean and were confirmed by three independent experiments. ${ }^{*} \mathrm{P}<0.05$ and ${ }^{* *} \mathrm{P}<0.01$, vs. control; ${ }^{\$} \mathrm{P}<0.05$, vs. $100 \mathrm{nM}$ AngII. C, control; Ang, angiotensin; LOS, losartan; Tyr, tyrosinase; AT1, Ang type 1.

$\mathbf{A}$

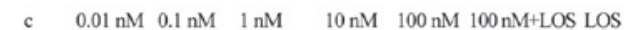
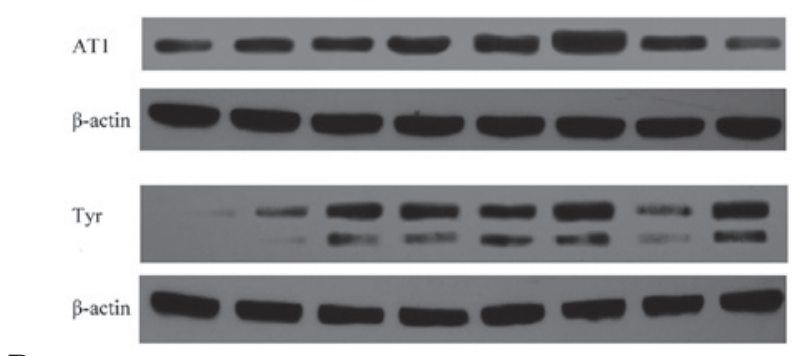

B

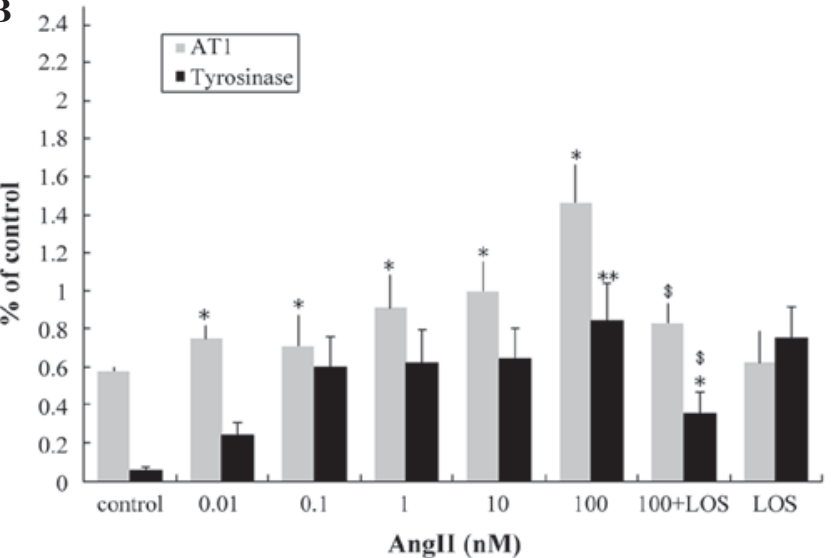

Figure 4. Effect of AngII on the protein expression levels of tyrosinase and AT1 in human melanocytes. (A) Western blot analysis of tyr and AT1 in the presence of different concentrations of AngII alone for $24 \mathrm{~h}$ or exposed to LOS $(1 \mu \mathrm{M})$ for 30 min prior to AngII stimulation. (B) Protein expression levels of tyrosinase and AT1 were quantified and normalized against $\beta$-actin. The data are expressed as the mean \pm standard error of the mean and were confirmed by three independent experiments. ${ }^{*} \mathrm{P}<0.05$ and ${ }^{* *} \mathrm{P}<0.01$, vs. control; ${ }^{\$} \mathrm{P}<0.05$, vs. $100 \mathrm{nM}$ AngII. C, control; Ang, angiotensin; LOS, losartan; Tyr, tyrosinase; AT1, Ang type 1. following wound healing remains to be elucidated. Notably, the localization of AngII and its receptors in the skin $(10,11,21)$ has suggested the possibility of a prominent pathological role for AngII, as demonstrated by previous studies investigating wounding healing in skin $(11,22)$.

The present study aimed to characterize the expression and function of AngII receptors in human melanocytes and investigate the contribution of AngII to abnormal pigmentation. AngII regulated the expression of the ATl receptor in human melanocytes, confirming that these receptors are functional in this cell type. In addition, it was demonstrated that AngII alters normal human melanocyte physiology, leading to a potentially favorable upregulation of tyrosinase. A previous study examining the localization of the $A T 1$ and $A T 2$ receptors in whole human skin using immunohistochemistry, revealed the expression of AT1 receptors in melanocytes, but not AT2 receptors (10). The present study utilized molecular biology techniques, directly applied to isolated human melanocytes. Using this approach, it was confirmed that AT1 receptors are expressed in human melanocytes as mRNA and protein, consistent with Steckelings et al (10). However, the relative expression levels of these receptors in melanocytes remain to be elucidated. Based on the fact that $A T 1$ receptors confer an active physiological role to AngII, their regulation becomes essential in determining the action of AngII. Investigating the regulation of the expression of these receptors may assist in understanding how they are involved in either physiological or pathological events. In the present study, the melanocytes expressed markedly low levels of AT1 receptor subtypes in the complete absence of AngII or in the presence of $0.01 \mathrm{nM}$ AngII. Treatment with $0.1 \mathrm{nM}$ AngII increased the expression of the AT1 receptor. By contrast, higher concentrations of AngII (1-100 $\mathrm{nM}$ ) increased the expression levels of the AT1 receptor in a dose-dependent manner. These effects were AngII receptor-mediated as the AngII receptor antagonist, LOS, eliminated the effects of AngII on the transcriptional regulation of the $A T 1$ receptors in the melanocytes. This is supported by evidence that the AT1/AT2 receptors are involved in pathological events in other tissue types (23-25). A previous study determined that $A T 1$ receptors are expressed in human skin (10), and the present study confirmed that AngII regulated the $A T 1$ receptors at the transcriptional level in melanocytes. Whether these receptors are functional in this cell type was also investigated. It has been reported that the $A T 1$ receptor belongs to the $\mathrm{G}$ protein-coupled, seven-transmembrane receptor family $(24,26)$. The present study demonstrated that stimulation of the ATI receptor by AngII is transduced into an intracellular signal, increasing the levels of tyrosinase. This result provides evidence that the AT1 receptor expressed in human melanocytes is functionally active and may be efficiently coupled to the tyrosinase transduction pathway, however, upregulation of the ATl receptor transduction pathway remains to be investigated. Melanocytes are central in the pathogenesis of abnormal pigmentation and, although the cellular mechanism underlying abnormal pigmentation remain to be elucidated, evidence suggests that tyrosinase may be involved $(19,27)$. Previous studies have demonstrated that physical stimuli regulate the activity of tyrosinase (28). The present study investigated whether AngII affects the regulation of tyrosinase and observed an increase in the mRNA and 
protein expression levels of tyrosinase. In addition, the ATI antagonist, LOS, eliminated the effect of AngII on tyrosinase activity and melanin content, indicating that AngII induced the pigmentation changes by enhancing tyrosinase activity via the ATl receptor. The melanocytes were treated with AngII for only $24 \mathrm{~h}$, therefore the possibility that longer exposure may induce an increase in tyrosinase cannot be ruled out.

The levels of tyrosinase protein were increased following exposure to $100 \mathrm{nM}$ AngII, via the $A T 1$ receptors, suggesting a synergistic effect of the $A T l$ receptor on tyrosinase upregulation in human melanocytes. This suggested that certain effects induced by AngII may be specific to the type of cell targeted. The present study demonstrated that AngII receptor inhibitors may prevent these changes.

Notably, the results of the present study suggested a potential role for AngII in tyrosinase regulation through the ATl receptors, and supported an association between AngII, tyrosinase and $A T 1$ receptor activation, which may be involved in abnormal pigmentation by upregulating tyrosinase in melanocytes.

The identification of functional ATl receptors in human melanocytes has provided novel insights into melanocyte physiology. The nature of these receptors, their additional functional activities and their regulatory mechanism require further investigation to assess the role of AngII in cutaneous pathophysiology.

\section{Acknowledgements}

The authors would like to thank the staff at the Department of Dermatology, General Hospital of Beijing Military of PLA (Beijing, China) for their assistance during the preparation of this manuscript. The authors would also like to thank Professor Junhong Ao for their technical assistance and Professor Wenling Wang for their critical reading of the manuscript. This study was supported by grants from the Foundation of Capital Medical Development and Research (no. 2007-3027) and the Second Five-Year Plan of Military Medical Science and Technology Research Foundation (no. CWS11J218).

\section{References}

1. Wisely JA, Hoyle E, Tarrier N and Edwards J: Where to start? Attempting to meet the psychological needs of burned patients. Burns 33: 736-746, 2007.

2. Zeitlin RE: Long-term psychosocial sequelae of paediatric burns. Burns 23: 467-472, 1997.

3. Singer AJ and Clark RA: Cutaneous wound healing. N Engl J Med 341: 738-746, 1999.

4. Rodgers K, Xiong S, Felix J, Roda N, Espinoza T, Maldonado S and Dizerega G: Development of angiotensin (1-7) as an agent to accelerate dermal repair. Wound Repair Regen 9: 238-247, 2001.

5. Kim JA, Berliner JA and Nadler JL: Angiotensin II increases monocyte binding to endothelial cells. Biochem Biophys Res Commun 226: 862-868, 1996.

6. Reddy HK, Sigusch H, Zhou G, Tyagi SC, Janicki JS and Weber KT: Coronary vascular hyperpermeability and angiotensin II. J Lab Clin Med 126: 307-315, 1995.
7. Steckelings UM, Artuc M, Paul M, Stoll M and Henz BM: Angiotensin II stimulates proliferation of primary human keratinocytes via a non-AT1, non- AT2 angiotensin receptor. Biochem Biophys Res Commun 229: 329-333, 1996.

8. Takeda H, Katagata Y, Hozumi Y and Kondo S: Effects of angiotensin II receptor signaling during skin wound healing. Am J Pathol 165: 1653-1662, 2004.

9. Rodgers K, Abiko M, Girgis W, St Amand K, Campeau J and diZerega G: Acceleration of dermal tissue repair by angiotensin II. Wound Repair Regen 5: 175-183, 1997.

10. Steckelings UM, Wollschläger T, Peters J, Henz BM, Hermes B and Artuc M: Human skin: source of and target organ for angiotensin II. Exp Dermatol 13: 148-154, 2004.

11. Nozawa Y, Matsuura N, Miyake H, Yamada S and Kimura R: Effects of TH-142177 on angiotensin II-induced proliferation, migration and intracellular signaling in vascular smooth muscle cells and on neointimal thickening after balloon injury. Life Sci 64: 2061-2070, 1999.

12. Steckelings UM, Henz BM, Wiehstutz S, Unger T and Artuc M: Differential expression of angiotensin receptors in human cutaneous wound healing. Br J Dermatol 153: 887-893, 2005.

13. Otake AH, Mattar AL, Freitas HC, et al: Inhibition of angiotensin II receptor 1 limits tumor-associated angiogenesis and attenuates growth of murine melanoma. Cancer Chemother Pharmacol 66: 79-87, 2010.

14. Bradford MM: A rapid and sensitive method for the quantitation of microgram quantities of protein utilizing the principle of protein-dye binding. Anal Biochem 72: 248-254, 1976.

15. Lei TC, Virador VM, Vieira WD and Hearing VJ: A melanocyte-keratinocyte coculture model to assess regulators of pigmentation in vitro. Anal Biochem 305: 260-268, 2002.

16. Virador VM, Kobayashi N, Matsunaga J and Hearing VJ: A standardized protocol for assessing regulators of pigmentation. Anal Biochem 270: 207-219, 1999.

17. Marin-Castaño ME, Elliot SJ, Potier M, et al: Regulation of estrogen receptors and MMP-2 expression by estrogens in human retinal pigment epithelium. Invest Ophthalmol Vis Sci 44: 50-59, 2003.

18. Peng Y, Kang Q, Cheng H, et al: Transcriptional characterization of bone morphogenetic proteins (BMPs)-mediated osteogenic signaling. J Cell Biochem 90: 1149-1165, 2003.

19. De Gasparo M, Catt KJ, Inagami T, Wright JW and Unger T: International union of pharmacology. XXIII. The angiotensin II receptors. Pharmacol Rev 52: 415-472, 2000.

20. Striker GE, Praddaude F, Alcazar O, Cousins SW and Marin-Castaño ME: Regulation of angiotensin II receptors and extracellular matrix turnover in human retinal pigment epithelium: roleof angiotensin II. Am J Physiol Cell Physiol 295: C1633-C1646, 2008.

21. Olivares C and Solano F: New insights into the active site structure and catalytic mechanism of tyrosinase and its related proteins. Pigment Cell Melanoma Res 22: 750-760, 2009.

22. Yahata Y, Shirakata Y, Tokumaru S, et al: A novel function of angiotensin II in skin wound healing. Induction of fibroblast and keratinocyte migration by angiotensin II via heparin-binding epidermal growth factor (EGF)-like growth factor-mediated EGF receptor transactivation. J Biol Chem 281: 13209-13216, 2006.

23. Huang W, Yu LF, Zhong J, et al: Angiotensin II type 1 receptor expression in human gastric cancer and induces MMP2 and MMP9 expression in MKN-28 cells. Dig Dis Sci 53: 163-168, 2008.

24. Sarlos S, Rizkalla B, Moravski CJ, Cao Z, Cooper ME and Wilkinson-Berka JL: Retinal angiogenesis is mediated by an interaction between the angiotensin type 2 receptor, VEGF and angiopoietin. Am J Pathol 163: 879-887, 2003.

25. Wolf G: Angiotensin II and tubular development. Nephrol Dial Transplant 17 (Suppl 9): 48-51, 2002.

26. Kaschina E and Unger T: Angiotensin AT1/AT2 receptors: regulation, signalling and function. Blood Press 12: 70-88, 2003.

27. Iozumi K, Hoganson GE, Pennella R, Everett MA and Fuller BB: Role of tyrosinase as the determinant of pigmentation in cultured human melanocytes. J Invest Dermatol 100: 806-811, 1993.

28. Yamaguchi Y and Hearing VJ: Physiological factors that regulate skin pigmentation. Biofactors 35: 193-199, 2009. 